\title{
Faktor-Faktor yang Mempengaruhi Kejadian Plasenta Previa Di Rumah Sakit Umum Daerah Kota Prabumulih
}

\author{
Dwi Saputri Mayang Sari ${ }^{1 *}$, Yudi Budianto ${ }^{2}$ \\ ${ }^{1}$ Program Studi Diploma III Kebidanan Akademi Kebidanan Rangga Husada Prabumulih \\ ${ }^{2}$ STIKES Al Ma'arif Baturaja \\ *Correspondence email: dwisaputri028@gmail.com
}

\begin{abstract}
Abstrak. Plasenta previa adalah salah satu risiko dalam kehamilan plasenta juga yang berimplantasi pada segmen bawah rahim. Tujuanya mengetahui faktor-faktor apa saja yang mempengaruhi kejadian plasenta previa. Metode penelitian ini bersifat analitik, dengan mengunakan pendekatan Cross Sectional. Populasi ini adalah semua ibu bersalin diruang kebidanan Rumah Sakit Umum Daerah Kota Prabumulih sebanyak 1712 orang. Sampel penelitian yaitu sebagian dari populasi yang berjumlah 324 orang. Instrumen penelitian berupa checklist. Hasil penelitian berdasarkan analisa univariat diketahui bahwa dari 324 responden terdapat 53 responden $(16,4 \%)$ yang mengalami plasenta previa dan 271 responden $(83,6 \%)$ yang tidak mengalami plasenta previa, terdapat 22 responden $(6,8 \%)$ yang didiagnosa mengalami kehamilan ganda dan 302 responden (93,2\%) yang tidak didiagnosa mengalami kehamilan ganda, terdapat 51 responden (15,7\%) yang memiliki riwayat kuretage dan 273 orang (84,3\%) yang tidak memiliki riwayat kuretage, terdapat 21 responden $(6,5 \%)$ yang mengalami tumor dan 303 orang $(93,5 \%)$ yang tidak mengalami tumor. Hasil dari analisa bivariat diketahui ada hubungan yang signifikan antara kehamilan ganda dengan kejadian plasenta previa dengan nilai $p$-value $0,000<\alpha 0,05$, ada hubungan yang signifikan antara riwayat kuretage dengan kejadian plasenta previa dengan nilai $p$-value $0,000<0,05$ dan ada hubungan yang siginifikan antara tumor dengan kejadian plasenta previa dengan nilai p-value $0,000<0,05$.
\end{abstract}

Kata Kunci: Plasenta Previa; Kehamilan Ganda; Riwayat Kuretage; Tumor

\begin{abstract}
Placenta previa is a one of the risks in pregnancy. The research objectives are the factors that influence the incidence of placenta previa in the City Hospital of Prabumulih in 2019. The research method is analytic, using the Cross Sectional approach. The population of this research was all of the maternity mothers in the midwifery room of the Prabumulih City which were 1712 people. The research sample is part of the population of 324 people. The research instrument was a checklist. The results of the study based on univariate analysis revealed that from 324 respondents there were 53 respondents (16.4\%) who had placenta previa and 271 respondents (83.6\%) who did not have placenta previa, there were 22 respondents (6.8\%) who were diagnosed with multiple pregnancy and 302 respondents (93.2\%) who were not diagnosed with multiple pregnancy, there were 51 respondents (15.7\%) who had a history of curettage and 273 people (84.3\%) who had no history of curettage, there were 21 respondents ( $6.5 \%)$ who had a tumor and 303 people (93.5\%) who did not have a tumor. From the bivariate analysis it is Conclusion there is a significant relationship between multiple pregnancy with the incidence of placenta previa with a P value of $0.000<\alpha 0.05$, there is a significant relationship between the history of curettage with the incidence of placenta previa with a value of $P$ value 0,000<0.05 and there is a significant relationship between the tumor and the incidence placenta previa with a $P$ value of $0,000<0.05$
\end{abstract}

Keywords: Placenta Previa; Multiple Pregnancy; History Of Kuretage; Tumor

\section{PENDAHULUAN}

Indikator dalam mengetahui perkembangan kesehatan ibu melalui Angka Kematian Ibu (AKI) yaitu menggambarkan banyaknya jumlah kematian perempuan yang dapat dilihat dari penyebab kematian terkait dengan masa kehamilan, proses kelahiran, dan masa nifas (WHO, 2016).

Perdarahan salah satu dapat menyebabkan kematian ibu yang sering terjadi pada masa kehamilan, pada proses kelahiran kemudian pada masa nifas. penyebab belum diketauhi secara pasti perdarahan adalah plasenta previa merupakan plasenta yang berimplantasi di segmen bawah rahim sehingga menutupi seluruh atau sebagian dari ostium uteri internum (Prawirohardjo, 2016).

Menurut data World Health Organization (WHO) memperkirakan 830 seorang perempuan yang meninggal setiap harinya akibat komplikasi pada masa kehamilan dan proses persalinan dari seluruh kematian ibu yang terjadi dinegara berkembang disebabkan oleh kehamilan obesitas $(28 \%)$, perdarahan $(30 \%)$, abortus $(8 \%)$, infeksi $(11 \%)$, hipertensi $(14 \%)$ dan penyebab lainnya (9\%), sedangkan untuk jumlah angka kematian bayi (AKB) sebesar 30,5 per $1.000 \mathrm{KH}$ dengan penyebabnya yaitu Asfiksia (11\%), Sepsis (7\%), kelainan bawaan (5\%), Pneumonia (3\%), Tetanus (1\%) dan penyebab lainnya (3\%).

Menurut survey demografi kesehatan Indonesia (SDKI) Penyebab banyaknya komplikasi pada ibu di Indonesia yaitu salah satunya sebanyak 40-60\% perdarahan, Preeklamsi dan Eklamsi 20-30\% dan infeksi 20-30\% (SDKI, 2012).

Plasenta previa merupakan plasenta yang berimplantasi pada segmen bawah Rahim, disaat usia 
kehamilan lebih dari 20 minggu, pada ibu yang mengalami perdarahan antepartum yaitu ibu akan mengalim syok, anemia dan dapat berakhir pada kematian. Pada janin juga biasanya akan terjadinya persalinan premature dan dapat terjadi komplikasi asfiksia berat pada bayi (Prawirohardjo, 2016).

Faktor penyebab dari plasenta previa sampai saat ini belum dapat diketahui secara pasati, namun ada beberapa factor yang meningkatkan kemungkinan terjadinya plasenta previa dan diduga berperan pada plasenta previa yaitu umur, paritas, jarak kehamilan, tumor, kehamilan ganda, serta riwayat endometrium (bekas operasi, kuretase dan plasenta manual) (Manuaba, 2015).

Pada kehamilan kembar atau gamelli khususnya dengan dua janin dan dua plasenta atau lebih dapat membuat satu tempat terjadinya implantasi plasenta yang lain akan memilih tempat yang kurang tepat untuk berimplantasi yaitu di segmen bawah rahim. Kalaupun hanya terdapat satu plasenta.

plasenta tersebut cenderung melebar untuk menutupi kebutuhan janin sehingga dapat menutupi sebagian atau seluruh ostium uteri internum (Indah Trianingsih. 2015).

Pada riwayat obstetrik riwayat kuretage, atau operasi seksio caesaria, faktor resiko plasenta previa yaitu endometrium yang cacat dan dimana terdapat berkas persalinan yang berulang dengan jarak yang pendek. Dapat dilihat pada efek samping dilakukan kuretage yaitu dapat berakibat dibagian tertentu uterus yang rapuh sehingga pada saat ibu mengalami kehamilan kemabil, nidasi yang terjadi tidak akan sempurna, dan dapat menyebabkan plasenta melekat pada segmen bawah uterus (Wikjonosastro. 2017).

Tumor dapat menyebabkan plasenta previa dalam hal ini mioma uteri dan polip endometrium karena biasanya mioma dan polip dapat tumbuh pada fundus uteri sehingga dalam kehamilan plasenta akan mencari tempat yang masih tersedia untuk berimplantasi. Disamping itu tumor yang membesar dalam uterus dapat menekan plasenta sehingga bergeser dan menutupi ostium uteri internum (Indah Trianingsih. 2015).

Penelitian ini bertujuan untuk menentukan faktorfaktor apa saja yang dapat mempengaruhi kejadian plasenta previa. Berdasarkan latar belakang diatas maka penulis tertarik untuk melakukan penelitian

kesehatan yang berjudul "Faktor-Faktor Yang Mempengaruhi Kejadian Palsenta Previa Di Rumah Sakit Umum Daerah Kota Prabumulih"

\section{METODE}

Pada hasil yang dilakukan adalah akan menggunakan penelitian study analityk yaitu Cross Sectional Study (Notoatmodjo, 2010).
Dimana variabel independen pada penelitian ini yaitu kehamilan ganda, riwayat kuretase dan tumor sedangkan variabel dependen yaitu plasenta previa.

Populasi merupakan seluruh responden dari penelitian atau responden yang diteliti (Notoatmodjo, 2010). Populasi saat ini yang diambil semua ibu yang melakukan persalinan diruang kebidanan Rumah Sakit Umum Daerah Kota Prabumulih.

Sampel adalah perwakilan populasi yang akan diteliti. Sampel dalam penelitian ini menggunakan teknik Random Sampling (Notoatmodjo, 2010).

Tempat penelitian dilakukan di rumah sakit umum daerah kota prabumulih, waktu penelitian dialksanakan pada tahun 2021.

\section{HASIL DAN PEMBAHASAN \\ Hasil analisa univariat}

Tabel 1. Distribusi Responden Menurut Kejadian Plasenta Previa, Kehamilan Ganda, Riwayat Kuretage Dan Tumor

\begin{tabular}{cccc}
\hline No & Karakteristik & Frekuensi & $\mathbf{( \% )}$ \\
\hline & Plasenta Previa & & \\
2 & Ya & 53 & 16,4 \\
& Tidak & 271 & 83,6 \\
3 & Kehamilan Ganda & & \\
4 & Ya & 22 & 6,8 \\
& Tidak & 302 & 93,2 \\
5 & Riwayat Kuretage & & \\
6 & Ya & 51 & 15,7 \\
& Tidak & 273 & 84,3 \\
7 & Tumor & & \\
8 & Ya & 21 & 6,5 \\
& Tidak & 303 & 93,5 \\
\hline
\end{tabular}

Berdasarkan tabel diatas, dari 324 responden terdapat 53 responden $(16,4 \%)$ yang mengalami plasenta previa lebih sedikit dibanding dengan yang tidak mengalami plasenta previa yaitu 271 responden $(83,6 \%)$. Dari kehamilan ganda terdapat 324 responden terdapat 22 responden $(6,8 \%)$ yang didiagnosa mengalami kehamilan ganda lebih sedikit dibanding dengan responden yang tidak didiagnosa mengalami kehamilan ganda yaitu 302 responden $(93,2 \%)$. Dari data riwayat kuretage didapatkan 324 responden terdapat 51 responden $(15,7 \%)$ yang memiliki riwayat kuretage lebih sedikit dibanding dengan responden yang tidak memiliki riwayat kuretage yaitu 273 orang $(84,3 \%)$. Dan dari hasil distribusi tumor didapatkan 324 responden terdapat 21 responden $(6,5 \%)$ yang mengalami tumor lebih sedikit dibanding dengan responden yang tidak mengalami tumor yaitu 303 orang $(93,5 \%)$.

\section{Hasil Analisis Bivariat}

Analisa bivariat ini untuk faktor-faktor yang mempengaruhi kejadian plasenta previa di RSUD Kota Prabumulih Tahun 2019. Uji statistik yang digunakan adalah uji chi square, dengan tingkat kemaknaan 0,05 
pada $\mathrm{df}=1$ bila $\mathrm{p}$ value $\leq 0,05$ berarti ada hubungan yang bermakna (signifikan) dan bila $p$ value $>0,05$ berarti tidak ada hubungan yang bermakna.

Tabel 2. Hubungan Antara Kehamilan Ganda Dengan Kejadian Plasenta Previa

\begin{tabular}{|c|c|c|c|c|c|c|c|}
\hline \multirow{3}{*}{$\begin{array}{c}\text { Kehamilan } \\
\text { Ganda }\end{array}$} & \multicolumn{6}{|c|}{ plasenta previa } & \multirow{3}{*}{$\begin{array}{c}P \text { - } \\
\text { Value }\end{array}$} \\
\hline & \multicolumn{2}{|c|}{ Ya } & \multicolumn{2}{|c|}{ Tidak } & \multicolumn{2}{|c|}{ Jumlah } & \\
\hline & $\mathbf{n}$ & $\%$ & n & $\%$ & $\mathbf{N}$ & $\%$ & \\
\hline Ya & 18 & 5,6 & 4 & 1,2 & 22 & 6,8 & \\
\hline Tidak & 35 & 10,8 & 267 & 82,4 & 302 & 93,2 & 0,000 \\
\hline Jumlah & 53 & 16,4 & 271 & 83,6 & 324 & 100 & \\
\hline
\end{tabular}

Berdasarkan hasil analisa bivariat dengan Hasil Uji statistic Chi-Square didapatkan p-value $=0,000$ artinya kehamilan ganda dengan kejadian plasenta previa ada hubungan yang bermakna dengan nilai $p$ value $\leq 0,05$ yang berarti bahwa terdapat hubungan yang bermakna antara kehamilan ganda dengan kejadian plasenta previa.

Hasil penelitian ini sesuai dengan hasil penelitian Indah Trianingsih (2015) tentang faktor-faktor yang berpengaruh timbulnya kejadian dengan plasenta previa di RSUDAM Provinsi lampung tahun 2015, dari sampel 306 ibu bersalin diketahui bahwa terdapat nilai $\rho$-value 0,001 yang berarti adanya hubungan yang signifikan antara kehamilan ganda dengan kejadian plasenta previa.

Ibu yang mengalami kehamilan ganda dengan dua janin dan dua plasenta atau membuat satu tempat terjadinya implantasi plasenta dan yang lain akan memilih tempat yang kurang tepat untuk berimplantasi yaitu di segmen bawah rahim. Kalaupun hanya terdapat satu plasenta, plasenta tersebut cenderung melebar untuk menutupi kebutuhan janin sehingga sebagian dapat menutupi atau seluruh ostium uteri internum (Indah Trianingsih. 2015).

Tabel 3. Hubungan Antara Riwayat Kuretage Dengan Kejadian Plasenta Previa

\begin{tabular}{cccccccc}
\hline \multirow{2}{*}{$\begin{array}{c}\text { Riwayat } \\
\text { kuretage }\end{array}$} & \multicolumn{6}{c}{ Ya } & \multicolumn{2}{c}{ Tidak } & \multicolumn{2}{c}{ Jumlah } & \multirow{2}{*}{ P value } \\
\cline { 2 - 7 } & $\mathbf{n}$ & $\mathbf{\%}$ & $\mathbf{n}$ & $\mathbf{\%}$ & $\mathbf{N}$ & $\mathbf{\%}$ & \\
\hline Ya & 36 & 11,1 & 15 & 4,6 & 51 & 15,7 & \\
Tidak & 17 & 5,3 & 256 & 79 & 273 & 84,3 & 0,000 \\
Jumlah & $\mathbf{5 3}$ & $\mathbf{1 6 , 4}$ & $\mathbf{2 7 1}$ & $\mathbf{8 3 , 6}$ & $\mathbf{3 2 4}$ & $\mathbf{1 0 0}$ & \\
\hline
\end{tabular}

Berdasarkan anaslisa bivariat dengan Hasil Uji statistic Chi-Square didapatkan $p$-value $=0,000$ artinya antara riwayat kuretage dengan kejadian plasenta previa ada hubungan yang signifikan dengan nilai $p$ value $\leq 0,05$ yang berarti bahwa terdapat hubungan yang bermakna antara riwayat kuretage dengan kejadian plasenta previa.

Hasil yang telah dilakukan sesuai dengan hasil penelitian Menurut hasil penelitian Siti Maesaroh (2016) "faktor-faktor yang mempengaruhi dengan kejadian dengan plasenta previa di RSUD dr.H.Abdul Moeloek Provinsi Lampung tahun 2016”, dari sampel 372 ibu bersalin diketahui bahwa terdapat nilai $\rho$-value 0,015 yang berarti ada hubungan yang signifikan riwayat kuretage terhadap kejadian plasenta previa.

Kejadian keguguran sebagian besar berakhir dengan tindakan kuretage, tindakan kuretage yang dilakukan dapat menimbulkan berbagai komplikasi diantaranya adanya perdarahan, perforasi, infeksi, robekan pada uterus. Dengan adanya robekan pada uterus makadimungkinkan terjadinya jaringan parut (scar tissue) yang dimana ketika terjadi kehamilan berikutnya dapat mengakibatkan plasenta terbentuk tidak pada bagian superior uterus melainkan pada bagian bawah uterus, dimana hal tersebut meningkatkan resiko kejadian plasenta previa pada kehamilan berikutnya (Sitti Maesaroh. 2016).

Pada masa pelaksanaan kuretage yang menggunakan alat kuret (kuretage tajam) dapat menyebabkan luka yang cukup dalam pada dinding endometrium. Luka yang terjadi mengakibatkan gangguan vaskularisasi pada desidua sehingga kesuburan didinding endometrium semakin berkurang.

Dalam masa kehamilan plasenta akan berusaha mencukupi kebutuhan nutrisi janin, sehingga pada dinding endometrium yang tidak subur plasenta akan memperluas diri sehingga menutupi sebagian atau seluruh ostium uteri internum (Indah Trianingsih. 2015).

Tabel 4. Hubungan Antara Tumor Dengan Kejadian Plasenta Previa

\begin{tabular}{|c|c|c|c|c|c|c|c|}
\hline \multirow{3}{*}{ Tumor } & \multicolumn{6}{|c|}{ Plasenta Previa } & \multirow{3}{*}{$P$ value } \\
\hline & \multicolumn{2}{|c|}{ Ya } & \multicolumn{2}{|c|}{ Tidak } & \multicolumn{2}{|c|}{ Jumlah } & \\
\hline & $\mathbf{n}$ & $\%$ & $\mathbf{n}$ & $\%$ & $\mathbf{N}$ & $\%$ & \\
\hline $\mathrm{Ya}$ & 16 & 5 & 5 & 1,5 & 21 & 6,5 & \\
\hline Tidak & 37 & 11,4 & 266 & 82,1 & 303 & 93,5 & 0,000 \\
\hline Jumlah & 53 & 16,4 & 271 & 83,6 & 324 & 100 & \\
\hline
\end{tabular}

Berdasarkan analisa bivariat didapatkan hasil dengan Hasil Uji statistic Chi-Square didapatkan pvalue $=0,000$ artinya antara tumor dengan kejadian plasenta previa ada hubungan yang signifikan dengan nilai $p$ value $\leq 0,05$ yang bearti bahwa terdapat ada hubungan yang bermakna antara tumor dengan kejadian plasenta previa.

Sejalan dengan hasil penelitian yang dilakukan oleh Sitti aras diana (2018) tentang analisis faktor yang berisiko terhadap kejadian dengan plasenta previa di RSUD Pole wali Mandar tahun 2018, dari sampel 117 ibu bersalin diketahui bahwa terdapat nilai $\rho$-value 0,001 yang berarti ada nya hubungan yang signifikan antara tumor dengan kejadian plasenta previa.

Tumor merupakan neoplasma atau lesi padat yang terbentuk akibat pertumbuhan sel yang tidak semestinya. Sering disebut Mioma uteri yaitu tumor jinak yang struktur utamanya adalah otot polos rahim. Bahaya terhadap penyakit mioma apalagi pada masa kehamilan dapat terjadi kelainan letak plasenta dikarena mioma uteri ini bisa tumbuh dibagian dinding luar rahim pada 
otot rahim dan bisa juga dibagian dinding dalam rahim itu sendiri. Plasenta previa dapat terjadi akibat adanya endometrium yang cacat. Salah satu juga yang menyebabkan endometrium mengalami masalah yaitu karena adanya mioma uteri (Sitti Aras diana. 2018).

Penyebaba terjadinya plasenta previa oleh tumor dalam hal ini adalah mioma uteri dan polip endometrium karena biasanya mioma uteri dan polip ini tumbuh pada fundus uteri sehingga dalam kehamilan plasenta akan mencari tempat yang masih tersedia untuk berimplantasi yaitu di segmen bawah rahim sehingga menutupi ostium uteri internum. Di samping itu mioma uteri atau polip endometrium yang dapat membesar dalam uterus dan menekan plasenta sehingga bergeser dan menutupi ostium uteri internum (Indah Trianingsih. 2015).

\section{SIMPULAN}

Dari hasil penelitian di Rumah Sakit Umum Daerah Kota Prabumulih didapatkan seluruh jumlah responden 324 orang, kemudian dapat disimpulkan bahwa diketahui distribusi frekuensi lebih banyak ibu yang tidak didiagnosa plasenta previa dibandingkan dengan ibu yang didagnosa plasenta previa.diketahui juga frekuensi pada kehamilan ganda lebih banyak ibu yang tidak didiagnosa dengan kehamilan ganda, dan dilihat dari distribusi riwayat kuratage lebih banyak juga yang tidak ada riwayat kuretage, kemudian distribusi pada ibu yang didiagnosa mempunyai tumor sedikit dibandingkan dengan yang tidak didiagnosa tumor. Distribusi hubungan atau pengaruh dari tiga variabel didapatkan hasil yang signifikan dengan hasil statistik $p$ value $=(0,000)<0,05$ dan ada hubungan dan pengaruh dari variabel kehamilan ganda, riwayat kuretage dan tumor dengan kejadian plasenta previa di Rumah sakit umum daerah kota prabumulih.

\section{Saran}

Diharapakan kepada tenaga kesehatan di Poliklinik pemeriksaanpada ibu hamil dapat meningkatkan kualitas dan kuantitas pelayanan pemeriksaan kehamilan sehingga dapat mendeteksi kelainan-kelainan pada ibu dimasa kehamilan sejak dini dan meningkatkan penyuluhan tentang tanda-tanda bahaya kehamilan sehingga dapat menurunkan angka kejadian plasenta previa.

Bagi kepada masyarakat untuk dapat memahami tentang masalah-masalah atau dapat mendeteksi terjadinya bahaya dimasa kehamilan terutama komplikasi yaitu plasenta previa, dan diharpakan kepada ibu hamil untuk dapat secara rutin melakukan pemeriksakan kehamilannya sehingga kesehatan ibu dan janin dapat terjaga dengan baik selama masa kehamilan.

\section{DAFTAR PUSTAKA}

Indah Trianingsih. 2015. Faktor-faktor yang berpengaruh timbulnya kejadian dengan plasenta previa di RSUDAM Provinsi lampung tahun 2015.(http://www.Indah trianingsih. Blogspot.com diakses 20 Februari 2020).

Manuaba, Ida Bagus Gede. 2015. Ilmu Kebidanan, Penyakit Kandungan dan KB, Jakarta, ECG.

Notoatmodjo, S. 2010. Ilmu Kesehatan Masyarakat. Jakarta. Rineka Cipta

Prawirohardjo, Sarwono. 2016. Pelayanan Kesehatan Maternal dan Neonatal. Edisi Pertama. Jakarta. YBP-SP.

SDKI. 2012. Angka Kematian Ibu. Jakarta: Survei Demografi dan Kesehatan Indonesia

Sitti Maesaroh. 2016. faktor-faktor yang berhubungan dengan kejadian dengan plasenta previa di RSUD dr.H.Abdul Moeloek Provinsi Lampung tahun 2016.(http://www.SittiMaesaroh. Blogspot.com diakses 2 Desember 2020).

Sitti Aras diana. 2018. Analisis faktor yang berisiko terhadap kejadian dengan plasenta previa di RSUD Pole wali Mandar tahun 2018.(http://www.Sitti Aras Diana. Blogspot.com diakses 2 Desember 2020).

Wikjonosastro. 2017. Kapita Selekta Kedokteran. Edisi ketiga. Jakarta. Media Aesculapius.

World Health Organization (2016).Maternal Mortality.(Diunduh 12 Februari 2018). 